Research Article

\title{
Superparamagnetic Iron Oxide Decorated Indium Hydroxide Nanocomposite: Synthesis, Characterization and Its Photocatalytic Activity
}

\author{
C.Y. Chong'1, T.H.W. Lee ${ }^{1}$, J.C. Juan², Mohd Rafie Johan², C.F. Loke', K.H. Ng1', J.C. Lai ${ }^{3}$, \\ T.H. Lim ${ }^{1, *}$ \\ 1Department of Physical Science, Faculty of Applied Sciences, Tunku Abdul Rahman University College, Kuala \\ Lumpur 53300, Malaysia. \\ ${ }_{2}^{2}$ anotechnology \& Catalysis Research Centre, Institute of Advanced Studies, University of Malaya, Jalan \\ Universiti, Kuala Lumpur 50603, Malaysia. \\ ${ }_{3}^{3}$ Biopolymer Research Group, School of Chemical and Energy Engineering, Universiti Teknologi Malaysia, Skudai \\ 81310, Malaysia.
}

Received: $23^{\text {rd }}$ September 2021; Revised: 21st November 2021; Accepted: 29th November 2021 Available online: 14th December 2021; Published regularly: March 2022

\section{Abstract}

A simple and scalable liquid-based method was developed to produce a nanocomposite photocatalyst which was comprised of $\mathrm{Fe}_{3} \mathrm{O}_{4}$ nanoparticles $(4-5 \mathrm{~nm}$ ) decorated indium hydroxide nanorods (mean width $33 \mathrm{~nm}$ and average aspect ratio 2 -3). The nanocomposite was produced at $25{ }^{\circ} \mathrm{C}$ in water via a hydroxide-induced co-precipitation ensued by a cathodic reduction during which the non-magnetic $\mathrm{Fe}(\mathrm{OH})_{3}$ intermediate was reduced to magnetic $\mathrm{Fe}_{3} \mathrm{O}_{4}$ at $20 \mathrm{~V}$ within $1 \mathrm{~h}$. The incorporation of $\mathrm{Fe}_{3} \mathrm{O}_{4}$ nanoparticles served to bestow magnetic recoverability to the photocatalyst and helped enhance visible light absorption simultaneously. Interestingly, the addition of $\mathrm{Fe}^{3+}$ led to the formation of $\operatorname{In}(\mathrm{OH})_{3}$ nanorods rather than the commonly observed nanocubes. In comparison to the $\operatorname{In}(\mathrm{OH})_{3} \operatorname{sys}-$ tem having a band gap of $4.60 \mathrm{eV}$ ), the band gap of the $\mathrm{Fe}_{3} \mathrm{O}_{4} / \mathrm{In}(\mathrm{OH})_{3}$ nanocomposite produced was determined to be $2.85 \mathrm{eV}$ using the Tauc's plot method. The effective reduction in band gap is expected to allow better absorption of visible light which in turns should help boost its photocatalytic performance. The $\mathrm{Fe}_{3} \mathrm{O}_{4} / \mathrm{In}(\mathrm{OH})_{3}$ nanocomposite was structurally characterized using a combination of PXRD, FESEM, EDS, and TEM and its paramagnetic property was proven with a positive mass susceptibility measured to be $1.30 \times 10^{-5} \mathrm{~cm}^{3} . \mathrm{g}^{-1}$. Under visible light, a photocatalytic degradation efficiency of $83 \%$ was recorded within $1 \mathrm{hr}$ for the nanocomposite using methylene blue as a dye. The photocatalytically-active $\mathrm{Fe}_{3} \mathrm{O}_{4} / \mathrm{In}(\mathrm{OH})_{3}$ should have good potential in visible-light driven waste water degradation once further optimized.

Copyright (C 2021 by Authors, Published by BCREC Group. This is an open access article under the CC BY-SA License (https://creativecommons.org/licenses/by-sa/4.0).

Keywords: Superparamagnetic nanocomposite; Green Synthesis; Visible Light Based Photodegradation; Methylene Blue

How to Cite: C.Y. Chong, T.H.W. Lee, J.C. Juan, M.R. Johan, C.F. Loke, K.H. Ng, J.C. Lai, T.H. Lim (2022). Superparamagnetic Iron Oxide Decorated Indium Hydroxide Nanocomposite: Synthesis, Characterization and Its Photocatalytic Activity. Bulletin of Chemical Reaction Engineering \& Catalysis, 17(1), 113-126 (doi: 10.9767/bcrec.17.1.12352.113-126)

Permalink/DOI: https://doi.org/10.9767/bcrec.17.1.12352.113-126

\section{Introduction}

In recent years, nanomaterials and nanocomposites have received substantial attention

\footnotetext{
* Corresponding Author.

Email: limth@tarc.edu.my (T.H. Lim)
}

worldwide owing to their unique properties which are size, shape and composition dependent. Advancement in the field of nanocomposites and nanotechnology has together equipped researchers with effective tools suitable for fixing real-world problems which include targeted haz- 
ardous waste treatment, green energy harnessing and precise nanomedicines [1,2]. Consequently, the continuous development of novel nanocomposites and fine-tuning their properties for particular applications naturally become increasingly important and one way to achieve the improvement is via fine tuning the electronic, optical and magnetic properties of selected nanocomposites [2-5].

Nanocomposites have been widely applied in photocatalysis during which UV or solar radiation absorbed with the nanocomposites led to the formation of electron $\left(e^{-}\right)$-hole $\left(h^{+}\right)$pairs. The photogenerated electrons and holes then participated in the oxidation of waste species leading to successful waste degradation. To achieve high efficiency, often the recombination of electron-hole pairs must be suppressed or avoided at the time scale of the chemical reactions involved. A suppression could be achieved by introducing "traps" for electron and hole thus avoiding the unproductive recombination which produced only heat as an outcome [6,7]. Such traps could be created by integrating a wide-band gap semiconductor and a low-band gap semiconductor to form a nanocomposite. Additionally, the two materials chosen to be combined should allow the nanocomposite to absorb solar radiation efficiently in order to harvest sunlight which is freely available [8]. In addition to the capability to convert solar energy, a high recoverability of a nanocomposite/photocatalyst should also be considered as part of the design.

$\operatorname{In}(\mathrm{OH})_{3}$, a semiconductor with wide band gap $(5 \mathrm{eV})$ has been reported to outperform the well-studied $\mathrm{TiO}_{2}$ in certain niche but important applications, for instance during the degradation of gaseous organic compounds where the presence of surface $\mathrm{OH}^{-}$species was found to enhance the efficacy of UV-based photodegradation $[9,10]$. Yan et al. reported that a $\mathrm{In}(\mathrm{OH})_{3}$-based photocatalyst exhibited a photodegradation performance 3.5-6 times higher than a $\mathrm{P}_{25}-\mathrm{TiO}_{2}$ benchmark [10-12]. The application of $\operatorname{In}(\mathrm{OH})_{3}$ has only been mainly focused in the gas phase photodegradation and therefore it would be interesting to study its photodegradation performance in liquid phase.

Following our recent published work on the use of $\operatorname{In}(\mathrm{OH})_{3} / \mathrm{Ag} / \mathrm{C}$ nanocomposite to help photodegrade methylene blue in water [13], we report herein the design and successful green preparation of a new superparamagnetic nanocomposite based on nanoscale wide-band gap $\mathrm{In}(\mathrm{OH})_{3}$ and low-band gap magnetic $\mathrm{Fe}_{3} \mathrm{O}_{4}$. To the best of the authors' knowledge, this is the first report of a $\mathrm{Fe}_{3} \mathrm{O}_{4} / \mathrm{In}(\mathrm{OH})_{3}$ nanocomposite.
The $\mathrm{Fe}_{3} \mathrm{O}_{4} / \mathrm{In}(\mathrm{OH})_{3}$ nanocomposite was prepared in two steps: (1) A simple hydroxide coprecipitation in water under ambient conditions; and (2) A cathodic reduction at $20 \mathrm{~V}$ for 1 hr under ambient conditions. Structural characterization was carried out using a combination of Powder X-ray diffraction (PXRD), FieldEmission Scanning Electron Microscopy (FESEM), Transmission electron microscopes (TEM), Energy-dispersive X-ray spectroscopy (EDS), Dynamic light scattering (DLS), and Fourier Transform - Infra Red (FT-IR), while its optical and magnetic properties were quantified using UV-Vis absorption and magnetic susceptibility measurement. The colloidal stability of the nanocomposite was quantified by studying its zeta potential and its photocatalytic performance on the degradation of methylene blue dye was evaluated in a solar photocatalytic reactor.

\section{Materials and Methods}

Indium trichloride salt (99.995\%) was purchased from ACROS, New Jersey, USA and AR grade sodium hydroxide was from EMSURE®. Iron(III) chloride hexahydrate and polyvinylpyrrolidone (PVP) $\left(\mathrm{C}_{6} \mathrm{H}_{9} \mathrm{NO}\right) \mathrm{n}, \mathrm{M} . \mathrm{W} . \sim 40000$ were purchased from R\&M Chemicals, and VWR Chemicals respectively. All chemicals were used as received without further purification.

2.1 Preparation of Iron Hydroxide/ Indium Hydroxide $\left(\mathrm{Fe}(\mathrm{OH})_{3} / \mathrm{In}(\mathrm{OH})_{3}\right)$ Nanocomposite via Co-precipitation Method

$\mathrm{Fe}(\mathrm{OH})_{3} / \mathrm{In}(\mathrm{OH})_{3}$ nanoparticles were synthesised by first dissolving $\mathrm{InCl}_{3}(1.106 \mathrm{~g})$ and $\mathrm{FeCl}_{3} .6 \mathrm{H}_{2} \mathrm{O}(0.270 \mathrm{~g})$ in the solution containing $0.600 \mathrm{~g}$ of PVP in water $(25 \mathrm{~mL})$. A freshly prepared aqueous sodium hydroxide $(0.720 \mathrm{~g}$ in 20 $\mathrm{mL}$ water) was added dropwise into the metal ions solution to produce an orange/brown dispersion. The dispersion was centrifuged at $9000 \mathrm{rpm}$ at $4{ }^{\circ} \mathrm{C}$ and the product isolated and purified after three cycles of washing with water and centrifugation. The precipitate isolated was dried at $60{ }^{\circ} \mathrm{C}$ for 1 day.

\subsection{Synthesis of Indium Hydroxide Nanocubes}

Indium hydroxide nanocubes were synthesized by dissolving $\mathrm{InCl}_{3}$ (1.106 g) in the solution containing $0.600 \mathrm{~g}$ of $\mathrm{PVP}$ in water (25 $\mathrm{mL}) .18 \mathrm{mmol}$ of $\mathrm{NaOH}$ was prepared by dissolving $0.720 \mathrm{~g}$ of $\mathrm{NaOH}$ in $20 \mathrm{~mL}$ of distilled water. The $\mathrm{NaOH}$ solution was added dropwise into the metal ions solution to produce a white 
dispersion. The dispersion was centrifuged at $9000 \mathrm{rpm}$ at $4{ }^{\circ} \mathrm{C}$ and the product isolated and purified after three cycles of washing with water and centrifugation. The precipitate isolated was dried at $60{ }^{\circ} \mathrm{C}$ for 1 day.

2.3 Preparation of Iron oxide/Indium Hydroxide $\left(\mathrm{Fe}_{3} \mathrm{O}_{4} / \mathrm{In}(\mathrm{OH})_{3}\right)$ Nanocomposite via Cathodic Reduction and Electrophoretic Deposition

$\mathrm{Fe}_{3} \mathrm{O}_{4} / \mathrm{In}(\mathrm{OH})_{3}$ nanocomposite was synthesised from a dispersion of $\mathrm{Fe}(\mathrm{OH})_{3} / \mathrm{In}(\mathrm{OH})_{3}$ $(1.00 \mathrm{~g} / \mathrm{L})$ via means of ultrasonication. One gram of the $\mathrm{Fe}(\mathrm{OH})_{3} / \mathrm{In}(\mathrm{OH})_{3}$ nanocomposite was dispersed in $1 \mathrm{~L}$ of distilled water. The $\mathrm{pH}$ of the solution was adjusted to between 3-4 with diluted $\mathrm{H}_{2} \mathrm{SO}_{4}$. The solution was then transferred into a vessel and two electrodes connected to power supply was placed into the solution. Both electrodes were immersed in the solution at exactly half their lengths and cathodic reduction occurred at the bottom half of the cathode with an applied voltage of $20 \mathrm{~V}$ for 1 hour. The other half of the cathode was then flipped and submerged into the solution in order to fully coat the cathode for another 1 hour. $\mathrm{Fe}_{3} \mathrm{O}_{4} / \mathrm{In}(\mathrm{OH})_{3}$ nanocomposite collected on the cathode (see Figure 1) and was readily scrapped off from the stainless steel substrate (the cathode) after the reduction.
2.4 Structural Characterization of $\operatorname{In}(\mathrm{OH})_{3}, \mathrm{Fe}$ $(\mathrm{OH})_{3} / \mathrm{In}(\mathrm{OH})_{3}$ and $\mathrm{Fe}_{3} \mathrm{O}_{4} / \mathrm{In}(\mathrm{OH})_{3}$ Nanocomposites

The phases of nanomaterials produced were analysed via powder X-ray Diffraction employing a Panalytic Empyrean $\left(\mathrm{Cu} \mathrm{K}_{\alpha}\right.$, step size of $0.0260^{\circ} 2 \theta$, scanning range $\left.20-80^{\circ}\right)$. The morphology, size and elemental compositions of products were studied using a Field-emission Scanning Electron Microscope (Hitachi SU8200 operating at $5 \mathrm{kV}$ ) and Transmission Electron Microscope (Hitachi HT-7700 operating at 120 $\mathrm{kV}$ ). Both electron microscopes were coupled with an EDS detector (Genesis X-ray Microanalysis System) for elemental analysis. Fourier-transform infrared spectroscopy was carried out on a Shidmadzu IRTracer-100 to determine the presence of PVP surfactant while a Hitachi U-2900 UV-visible spectrophotometer was used to study their light absorption properties. Dynamic light scattering (DLS) and zeta potential were conducted using an Anton Parr Litesizer ${ }^{\text {TM}} 500$ and the magnetic susceptibility of the nanocomposites were quantified using a Gouy balance (Sherwood Scientific).

\subsection{Photocatalytic Degradation of Methylene Blue under Solar Radiation}

500 ppm methylene blue stock solution was prepared to produce a calibration curve. 5,10 , 15, 20, 25 and $30 \mathrm{ppm}$ of Methylene blue. First, $0.05 \mathrm{~g}$ of Methylene blue was weighed and add-
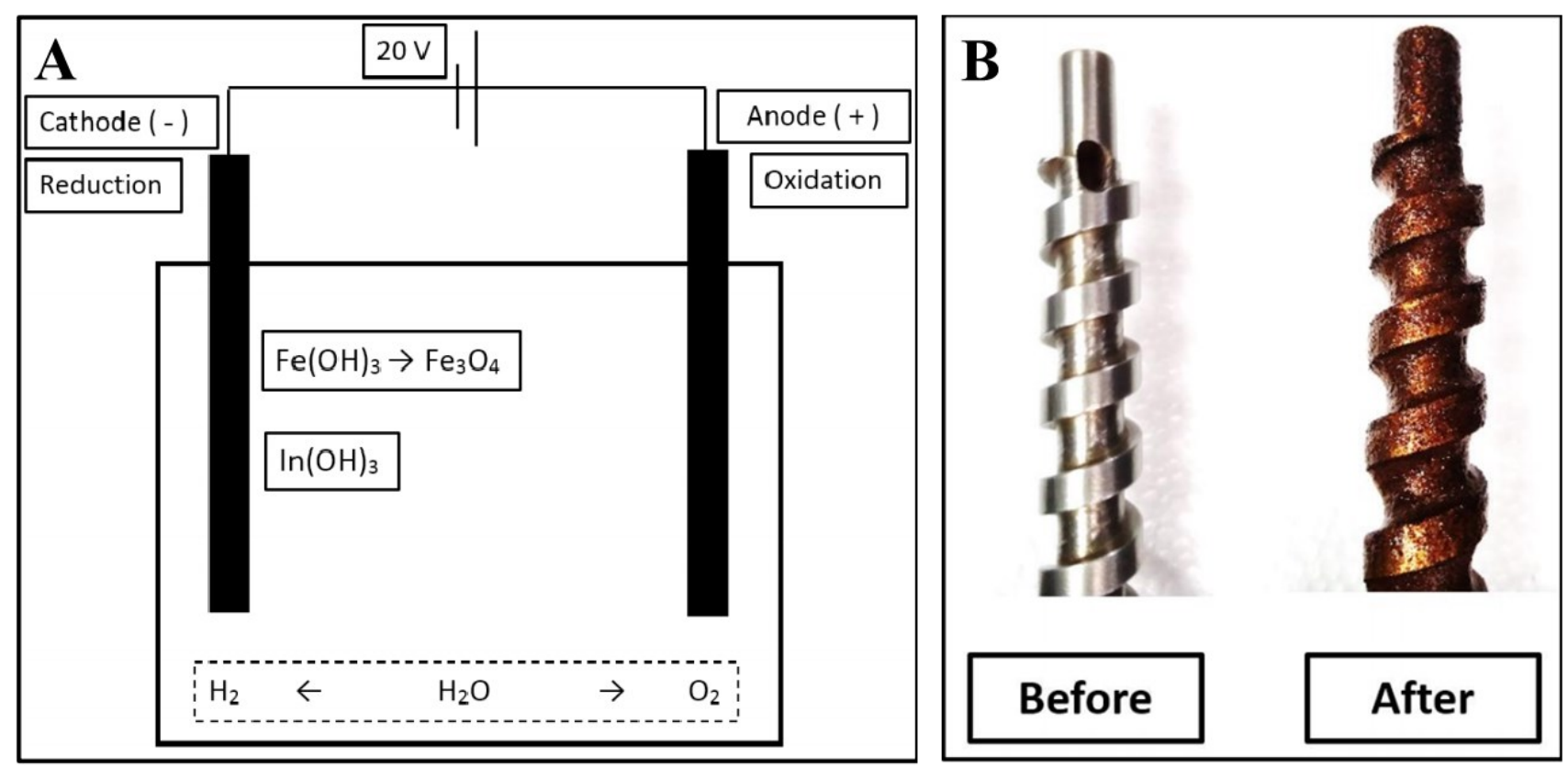

Figure 1. (A) A diagram shows the electrochemical cell set-up for the cathodic reduction and electrophoretic deposition of $\mathrm{Fe}(\mathrm{OH})_{3} / \mathrm{In}(\mathrm{OH})_{3}$ in the process of producing $\mathrm{Fe}_{3} \mathrm{O}_{4} / \mathrm{In}(\mathrm{OH})_{3}$ setup; and (B) Uniform brown coating comprised of $\mathrm{Fe}_{3} \mathrm{O}_{4} / \mathrm{In}(\mathrm{OH})_{3}$ observed on the cathode which was grey and metallic prior to electrophoretic deposition. 
ed into a $100 \mathrm{~mL}$ volumetric flask and topped up to the mark with distilled water. Next, 1, 2, $3,4,5$, and $6 \mathrm{~mL}$ of the stock solution were added to six $100 \mathrm{~mL}$ volumetric flasks respectively and topped up to the mark with distilled water. The standard solutions $(5,10,15,20,25$, and $30 \mathrm{ppm}$ ) were analysed by using UV-vis spectroscopy at $664 \mathrm{~nm}$ to establish a calibration curve (see Supporting Information Figure S1).

The photocatalytic performance of photocatalysts nanocomposite under solar radiation was tested with methylene blue. A dried powder of nanocatalysts $\left(\mathrm{InOH}_{3}, \mathrm{Fe}(\mathrm{OH})_{3} / \mathrm{In}(\mathrm{OH})_{3}\right.$ and $\left.\mathrm{Fe}_{3} \mathrm{O}_{4} / \mathrm{In}(\mathrm{OH})_{3}\right)$ stabilized on carbon (10 wt $\% 25 \mathrm{mg}$ ) was dispersed in a $25 \mathrm{~mL}$ of $25 \mathrm{ppm}$ methylene blue solution in a quartz tube. Dark absorption equilibrium was achieved within an hour with the absorbance of characteristic absorption wavelength at $664 \mathrm{~nm}$ becoming a constant. The absorbance at $664 \mathrm{~nm}$ was traced along reaction time after solar radiation (Xenon lamp operating at $150 \mathrm{~W}$ ) was turned on for an hour. For each measurement, a $5 \mathrm{~mL}$ sample solution was syringe filtered prior to a UV-Vis absorption measurement. The procedure was repeated with synthesised $\operatorname{In}(\mathrm{OH})_{3}$ and $\mathrm{Fe}(\mathrm{OH})_{3} / \mathrm{In}(\mathrm{OH})_{3}$ nanocomposite for comparisons. and A blank control without any nanocomposite added was studied in the same manner. The photodegradation efficiency (in \%) was calculated using Equation (1).

$$
\text { Photodegradation efficiency }=\frac{C_{0}-C_{t}}{C_{0}} \times 100 \%
$$

Alternatively, the ratio of $C_{t} / C_{o}$ may also provide the changes in concentration and the value of $\left(1-C_{t} / C_{o}\right)$ converted to percentage also yields the photocatalytic degradation efficiency of MB.

\section{Results and Discussion}

3.1 Synthesis of Superparamagnetic Iron Oxide/ Indium Hydroxide $\left(\mathrm{Fe}_{3} \mathrm{O}_{4} / \mathrm{In}(\mathrm{OH})_{3}\right.$ Nanocomposite)

The synthesis consisted of two steps with the first step focused on producing nonmagnetic iron hydroxide/indium hydroxide, $\mathrm{Fe}(\mathrm{OH})_{3} / \operatorname{In}(\mathrm{OH})_{3}$, as an intermediate. The water dispersible intermediate was then reduced to magnetic $\mathrm{Fe}_{3} \mathrm{O}_{4} / \mathrm{In}(\mathrm{OH})_{3}$ in water with a moderate voltage of $20 \mathrm{~V}$ and within 1 hour. The detailed synthesis is discussed in the following sections.

\subsection{Preparation of $\mathrm{Fe}(\mathrm{OH})_{3} / \mathrm{In}(\mathrm{OH})_{3}$ via Hy-} droxide Co-precipitation

A mole ratio $\operatorname{In}^{3+}: \mathrm{Fe}^{3+}$ of $5: 1$ was selected during the hydroxide induced co-precipitation of $\mathrm{Fe}(\mathrm{OH})_{3}$ and $\mathrm{In}(\mathrm{OH})_{3}$ in the presence of PVP. PVP played an important role as a surfactant to manipulate the nanoparticle size and to prevent nanoparticles from coalescence. The reaction of the co-precipitation is shown in Equation (2).

$$
\begin{gathered}
\mathrm{InCl}_{3(\mathrm{aq})}+\mathrm{FeCl}_{3(\mathrm{aq})}+6 \mathrm{NaOH} \rightarrow \mathrm{In}(\mathrm{OH})_{3(\mathrm{~s})}+ \\
\mathrm{Fe}(\mathrm{OH})_{3(\mathrm{~s})}+6 \mathrm{NaCl}_{(\mathrm{aq})}
\end{gathered}
$$

The Equation (2) shows the overall chemical reaction leading to the formation of intermediate nanocomposite $\mathrm{Fe}(\mathrm{OH})_{3} / \mathrm{In}(\mathrm{OH})_{3}$. The intermediate nanocomposite was purified via washing and centrifugation to remove excess PVP and sodium chloride as a by-product.

3.3 Fabrication of $\mathrm{Fe}_{3} \mathrm{O}_{4} / \mathrm{In}(\mathrm{OH})_{3}$ Nanocomposite via Cathodic Reduction and Electrophoretic Deposition

The intermediate nanocomposite comprised of $\mathrm{Fe}(\mathrm{OH})_{3}$ decorated $\operatorname{In}(\mathrm{OH})_{3}$ was a lightbrown powder with a tint of orange and was readily dispersed in water and isopropanol. After sonication, a stable dispersion of $\mathrm{Fe}(\mathrm{OH})_{3} / \mathrm{In}(\mathrm{OH})_{3}$ was subjected to cathodic reduction and electrophoretic deposition in an electrochemical cell depicted in Figure 1 A (see Supporting Information Figure S2 for a photo of the experimental set-up). The produced $\mathrm{Fe}_{3} \mathrm{O}_{4} / \mathrm{In}(\mathrm{OH})_{3}$ nanocomposite was deposited onto the stainless-steel-based cathode electrode having a continuous threading pattern on the surface. Electrophoretic deposition was selected because it allows an even coating to be produced and deposited on electrode relatively easily within few hours of fabrication time. It also allows a wide range of materials (polymers, metals, ceramics) to be deposited, thus a popular choice. The $\mathrm{Fe}_{3} \mathrm{O}_{4} / \mathrm{In}(\mathrm{OH})_{3}$ formed and coated on the steel, evidenced by the observation of a uniform brown layer appearing on the surface of the cathode which was silvery to start with (see Figure $1 \mathrm{~B}$ ).

Electrolysis of water proceeded at the anode following the equation described in Equation (3) when electric current was supplied to the system.

$$
\mathrm{H}_{2} \mathrm{O} \rightarrow 2 \mathrm{H}^{+}+2 \mathrm{e}^{-}+1 / 2 \mathrm{O}_{2}
$$

At cathode, reduction of water took place (Equation (4)): 


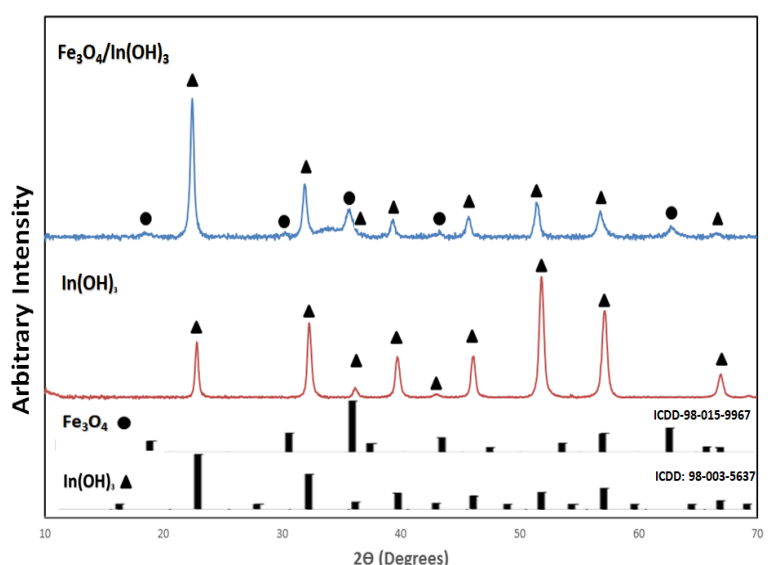

Figure 2. PXRD diffractograms of $\mathrm{Fe}_{3} \mathrm{O}_{4} / \mathrm{In}(\mathrm{OH})_{3}, \operatorname{In}(\mathrm{OH})_{3}$ produced were matched to $\mathrm{Fe}_{3} \mathrm{O}_{4}$ and $\mathrm{In}(\mathrm{OH})_{3}$. The strong intensity of (200) observed for $\mathrm{Fe}_{3} \mathrm{O}_{4} / \mathrm{In}(\mathrm{OH})_{3}$ is indicative of the preferential growth of anisotropic structure.

$$
2 \mathrm{H}_{2} \mathrm{O}+2 \mathrm{e}^{-} \rightarrow \mathrm{H}_{2}+2 \mathrm{OH}^{-}
$$

In order to increase the electrical conductivity of the system, sulfuric acid was added as an electrolyte which dissociated into ions according to Equation (5) and the protons moved toward the cathode as did $\mathrm{Fe}(\mathrm{OH})_{3} / \mathrm{In}(\mathrm{OH})_{3}$ nanocomposite. $\mathrm{Fe}(\mathrm{OH})_{3}$ attached to $\mathrm{In}(\mathrm{OH})_{3}$ was reduced to $\mathrm{Fe}_{3} \mathrm{O}_{4}$ based on Equation (6) forming an even brown product coating.

$$
\begin{aligned}
& \mathrm{H}_{2} \mathrm{SO}_{4} \rightarrow 2 \mathrm{H}^{+}+\mathrm{SO}_{4}{ }^{2-} \\
& 3 \mathrm{Fe}(\mathrm{OH})_{3(\mathrm{~s})}+\mathrm{H}^{+}+\mathrm{e}^{-} \rightarrow \mathrm{Fe}_{3} \mathrm{O}_{4}(\mathrm{~s}) \\
&
\end{aligned}
$$

Similar work related to the cathodic reduction of $\mathrm{Fe}(\mathrm{OH})_{3}$ to $\mathrm{Fe}_{3} \mathrm{O}_{4}$ was previously reported by Cabrera et al. in which magnetite $\left(\mathrm{Fe}_{3} \mathrm{O}_{4}\right)$ nanoparticles ranging from 20-30 nm were successfully synthesized [14].

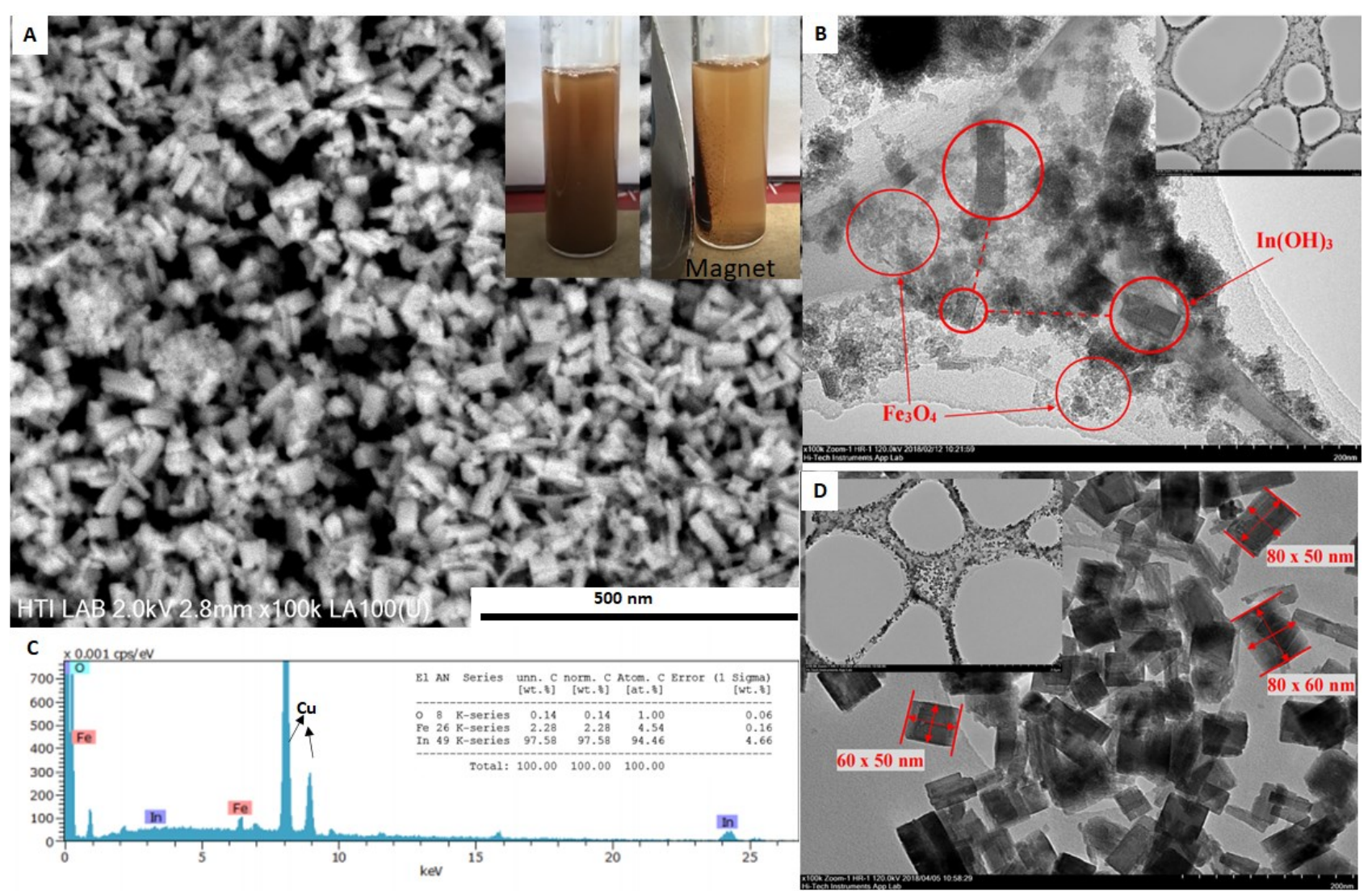

Figure 3. (A) SEI image of $\mathrm{Fe}_{3} \mathrm{O}_{4} / \mathrm{In}(\mathrm{OH})_{3}$ obtained in a FESEM shows rod shape structure with surface decoration. The inset shows the superparamagnetic property of the sample. Particles readily suspended in water and recovered using a permanent ferromagnet. (B) Bright field TEM image of $\mathrm{Fe}_{3} \mathrm{O}_{4} / \mathrm{In}(\mathrm{OH})_{3}$ shows nanorods $20-40 \mathrm{~nm}$ in width being decorated by nanoparticles of 4-5 nm. (C) EDS analysis shows the presence of indium, iron with atomic \% found to be 95 and $5 \%$ respectively. The strong $\mathrm{Cu}$ signals observed originated from the copper grid used in the TEM study. (D) Indium hydroxide nanocubes were produced where no $\mathrm{Fe}^{3+}$ was added and without electrophoresis. 


\subsection{Morphology and Structural Analyses}

Figure 2 shows a collection of PXRD diffractograms attained for $\mathrm{Fe}_{3} \mathrm{O}_{4} / \mathrm{In}(\mathrm{OH})_{3}$ and $\mathrm{In}(\mathrm{OH})_{3}$ produced and related standards. The nanocomposite was found to contain $\operatorname{In}(\mathrm{OH})_{3}$ as the major phase with $\mathrm{Fe}_{3} \mathrm{O}_{4}$ being the minority phase, evidenced by their matching to dzhalindite (ICDD: 98-003-5637) and magnetite (ICDD-98-015-9967), respectively. The stronger relative intensity observed for the (200) plane indicated a preferential growth of anisotropic $\operatorname{In}(\mathrm{OH})_{3}$. This observation matches well the findings by Wang et al. on $\operatorname{In}(\mathrm{OH})_{3}$ nanorods produced from hydroxide precipitation of indi- um chloride similar to that employed in this work $[15,16]$. From the full width half maxima of the (200) peak, average crystallite size of 23 $\mathrm{nm}$ (see Supporting Information Figure S3) was estimated using Scherrer equation- a strong indication that the products were in the nanoscale. Meanwhile, the average crystallite size estimated via Scherrer equation is correlated to the actual particle size distribution, morphology and size analyses using electron microscopies should provide more accurate description of the actual particle size and shape, especially for a complex nanorod/nanoparticles composite which is the $\mathrm{Fe}_{3} \mathrm{O}_{4} / \mathrm{In}(\mathrm{OH})_{3}$ synthesized [17].

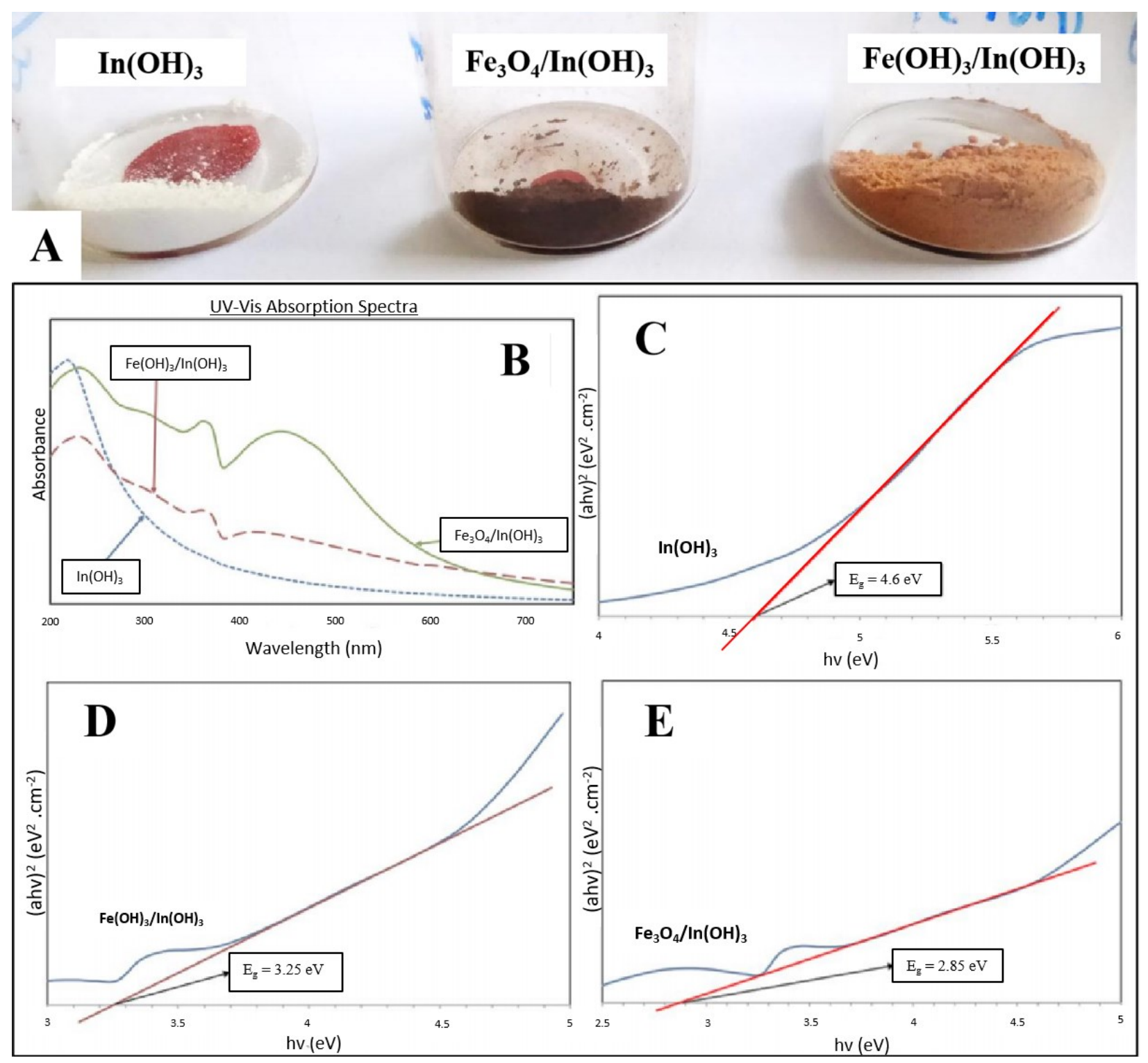

Figure 4. (A) A photograph of nanoscale $\operatorname{In}(\mathrm{OH})_{3}, \mathrm{Fe}_{3} \mathrm{O}_{4} / \mathrm{In}(\mathrm{OH})_{3}$ and $\mathrm{Fe}(\mathrm{OH})_{3} / \mathrm{In}(\mathrm{OH})_{3}$ isolated after purification and drying; (B) UV-Vis spectra of $\mathrm{In}(\mathrm{OH})_{3}, \mathrm{Fe}(\mathrm{OH})_{3} / \mathrm{In}(\mathrm{OH})_{3}$ and $\mathrm{Fe}_{3} \mathrm{O}_{4} / \mathrm{In}(\mathrm{OH})_{3}$ nanocomposites; (C) $\operatorname{In}(\mathrm{OH})_{3}$ nanocubes sample has a band gap calculated to be $4.6 \mathrm{eV}$ via Tauc's plot method; (D) Band gap of $\mathrm{Fe}(\mathrm{OH})_{3} / \mathrm{In}(\mathrm{OH})_{3}$ found to be $3.25 \mathrm{eV}$ and (E) Band gap of $\mathrm{Fe}_{3} \mathrm{O}_{4} / \mathrm{In}(\mathrm{OH})_{3}$ was determined to be $2.85 \mathrm{eV}$, signifying an enhanced visible light absorption capability in comparison to UV absorbing $\mathrm{In}(\mathrm{OH})_{3}$ and non-magnetic $\mathrm{Fe}(\mathrm{OH})_{3} / \mathrm{In}(\mathrm{OH})_{3}$ intermediate. 
Figure $3 \mathrm{~A}$ reveals that the $\mathrm{Fe}_{3} \mathrm{O}_{4} / \mathrm{In}(\mathrm{OH})_{3}$ nanocomposite produced consisted of uniformly sized nanorods decorated by smaller nanoparticles. The same morphologies were more obvious in the bright field TEM image (Figure $3 \mathrm{~B}$ ). The rods have similar width measured at $33-34 \mathrm{~nm}$ and slightly more varied length measured between 70-100 $\mathrm{nm}$, yielding an average aspect ratio between 2-3. Smaller nanoparticles of 4-5 $\mathrm{nm}$ were surrounding the nanorods (see Supporting Information Figure S4). EDS analysis revealed the nanocomposite was comprised of indium, iron and oxygen, with the indium to iron atom percentage being $95 \%$ to $5 \%$ atomic percent (Figure S5). In the absence of $\mathrm{Fe}^{3+}$, $\mathrm{In}(\mathrm{OH})_{3}$ cubes were obtained instead.

The co-precipitation of $\mathrm{In}^{3+}$ and $\mathrm{Fe}^{3+}$ is similar to sol-gel approaches known to produce uniform mixture in which the gel consists of certain $\mathrm{In}-\mathrm{OH}-\mathrm{Fe}$ network (in $\mathrm{Fe}(\mathrm{OH})_{3} / \mathrm{In}(\mathrm{OH})_{3}$ $[15,16]$. Following the cathodic reduction, $\mathrm{Fe}(\mathrm{OH})_{3}$ was converted to $\mathrm{Fe}_{3} \mathrm{O}_{4}$. It is expected that on the interface, In-O-Fe may be present. Such sharing was previously observed in $\mathrm{Sn}$ doped $\operatorname{In}(\mathrm{OH})_{3}$ prepared via a sol gel method and $\mathrm{Al}^{3+}$ doped ceria nanorods where "Al-O-Ce-O- clusters," were found in the nanocrystals [18].

3.5 Optical Properties Characterization via UVVIS Absorption

The optical properties of $\operatorname{In}(\mathrm{OH})_{3}$ and two nanocomposites synthesized were characterized using a UV-Vis absorption spectroscopy. Figure $4 \mathrm{~A}$ shows the colour of the three compounds under white light. The darker colour of $\mathrm{Fe}_{3} \mathrm{O}_{4} / \mathrm{In}(\mathrm{OH})_{3}$, relative to $\mathrm{Fe}(\mathrm{OH})_{3} / \mathrm{In}(\mathrm{OH})_{3}$ indicated the successful conversion of nonmagnetic $\mathrm{Fe}(\mathrm{OH})_{3}$ to magnetic $\mathrm{Fe}_{3} \mathrm{O}_{4}$ which should be darker in colour due to a smaller bandgap. The coloured appearances are also in congruence with results observed in the UV-Vis absorption spectra. $\mathrm{Fe}_{3} \mathrm{O}_{4} / \mathrm{In}(\mathrm{OH})_{3}$ absorbed strongly between $400-700 \mathrm{~nm}$, in comparison to the other two compounds, thus the origin of its dark brown appearance could be explained.

A Tauc's plot is a standard method commonly employed to determine the direct band gap of a nanocomposite by fitting the UV-Vis data to direct transition equation shown below (see reference [19]):

$$
a h v=A\left(h v-E_{g}\right)^{1 / 2}
$$

rearrange to:

$$
\begin{aligned}
& (a h v)^{2}=A^{2}(h v)-A^{2}\left(E_{g}\right) ; \\
& Y=m X+C
\end{aligned}
$$

In Equation (8), the parameters $a, h v, A$ and $E_{g}$ absorption coefficient, absorbance, photon energy and band gap, respectively. By taking the tangent and extrapolating it to intercept with the $\mathrm{x}$-axis, the band gap of a nanocomposite can be estimated. Figure 4C-4E show the band gap values of $4.6 \mathrm{eV}, 3.25 \mathrm{eV}$ and $2.85 \mathrm{eV}$ calculated for $\operatorname{In}(\mathrm{OH})_{3}, \quad \mathrm{Fe}(\mathrm{OH})_{3} / \mathrm{In}(\mathrm{OH})_{3}$ and $\mathrm{Fe}_{3} \mathrm{O}_{4} / \mathrm{In}(\mathrm{OH})_{3}$, respectively. The $\mathrm{In}(\mathrm{OH})_{3}$ synthesized in this work has band gap value similar to those reported by $\mathrm{Hu}$ et al. and Yan et al. where porous $\operatorname{In}(\mathrm{OH})_{3}\left(60{ }^{\circ} \mathrm{C}\right.$ and $120{ }^{\circ} \mathrm{C}$ treated) nanophotocatalysts synthesized exhibited red-shifted band gap value in between 4.5$4.7 \mathrm{eV}[10,11]$. The origin of the red shift may be attributed to the small degree of imperfection present in the $\operatorname{In}(\mathrm{OH})_{3}$ crystal and different chemical states induced on the surface due to the imperfection [10]. Such surface defect and chemical state of surface are considered beneficial because they could potentially act as traps for electrons and holes. The magnetic $\mathrm{Fe}_{3} \mathrm{O}_{4} / \mathrm{In}(\mathrm{OH})_{3}$ nanocomposite, with its band gap further red-shifted to the visible region at $2.85 \mathrm{eV}$, is expected to perform better as a photocatalyst under solar radiation when compared to the $\operatorname{In}(\mathrm{OH})_{3}$ or $\mathrm{Fe}(\mathrm{OH})_{3} / \mathrm{In}(\mathrm{OH})_{3}$ counterparts.

Table 1. Magnetic susceptibility of $\operatorname{In}(\mathrm{OH})_{3}, \mathrm{Fe}_{3} \mathrm{O}_{4} / \operatorname{In}(\mathrm{OH})_{3}$ and PVP.

\begin{tabular}{lccc}
\hline & $\begin{array}{c}\text { PVP-stabilized } \\
\mathrm{In}(\mathrm{OH})_{3}\end{array}$ & $\begin{array}{c}\text { PVP-Stabilized } \\
\mathrm{Fe}_{3} \mathrm{O}_{4} / \mathrm{In}(\mathrm{OH})_{3}\end{array}$ & PVP \\
\hline Calibration Constant & 01 & 01 & 01 \\
Mass of empty tube $(\mathrm{g})$ & 0.8604 & 0.8981 & 0.8609 \\
$\mathrm{R}_{\mathrm{o}}$ & -038 & -024 & -028 \\
Length of sample in tube $(\mathrm{cm})$ & 1.8 & 1.5 & 1.8 \\
Mass of sample and tube $(\mathrm{g})$ & 1.0396 & 0.9380 & 0.9243 \\
Mass of sample (g) & 0.1792 & 0.0399 & 0.0634 \\
$\mathrm{R}$ & -063 & 324 & -030 \\
Mass susceptibility $\left(X_{\mathrm{g}}\right)\left(\mathrm{cm}^{3} \cdot \mathrm{g}^{-1}\right)$ & $-2.5 \times 10^{-7}$ & $1.30 \times 10^{-5}$ & $-5.68 \times 10^{-8}$ \\
Molar susceptibility $\left(X_{\mathrm{m}}\right)\left(\mathrm{cm}^{3} \cdot \mathrm{mol}^{-1}\right)$ & $-4.15 \times 10^{-5}$ & $7.44 \times 10^{-3}$ & $-2.27 \times 10^{-3}$ \\
\hline
\end{tabular}


3.6 Magnetic Characterization of $\mathrm{Fe}_{3} \mathrm{O}_{4} / \mathrm{In}(\mathrm{OH})_{3}$ Nanocomposite

The magnetic susceptibility of $\mathrm{Fe}_{3} \mathrm{O}_{4} / \mathrm{In}(\mathrm{OH})_{3}, \operatorname{In}(\mathrm{OH})_{3}$ and PVP surfactant were evaluated employing a Gouy balance and the relationship shown in Equations (9) and (10).

$$
\begin{aligned}
& X_{m}=X_{g} \times \text { molar mass of sample } \\
& X_{g}=\frac{C l\left(R-R_{0}\right)}{10^{9} \mathrm{~m}}
\end{aligned}
$$

where, $X_{g}, C, l, R, R_{0}$, and $m$ represent mass susceptibility, the calibration constant, the length of a packed sample, reading for a sample, reading for an empty tube and the mass of a sample loaded, respectively.

By taking into account of the susceptibility of PVP, the $X_{m}$ value for $\mathrm{Fe}_{3} \mathrm{O}_{4} / \mathrm{In}(\mathrm{OH})_{3}$ was obtained by subtracting the susceptibility of PVPstabilized $\mathrm{Fe}_{3} \mathrm{O}_{4} / \mathrm{In}(\mathrm{OH})_{3}$ from that of PVP. The susceptibility of diluent PVP (surfactant used to stabilize the nanocomposite in this work) was first measured as it is also present in the susceptibility measurement of $\mathrm{Fe}_{3} \mathrm{O}_{4} / \mathrm{In}(\mathrm{OH})_{3}$ sample.

From the results in Table 1, both PVP and $\operatorname{In}(\mathrm{OH})_{3}$ were found to be diamagnetic with negative values obtained for both mass and molar susceptibilities [20,21]. $\mathrm{Fe}_{3} \mathrm{O}_{4} / \mathrm{In}(\mathrm{OH})_{3}$ nanocomposite was found to have net magnetization evidenced by a significantly larger positive magnetic susceptibility. Since $\operatorname{In}(\mathrm{OH})_{3}$ alone is diamagnetic, the magnetic properties of $\mathrm{Fe}_{3} \mathrm{O}_{4} / \operatorname{In}(\mathrm{OH})_{3}$ should, as expected, arisen from the $\mathrm{Fe}_{3} \mathrm{O}_{4}$ moiety. Bulk $\mathrm{Fe}_{3} \mathrm{O}_{4}$ (magnetite) is known to be a ferrimagnetic material which be-

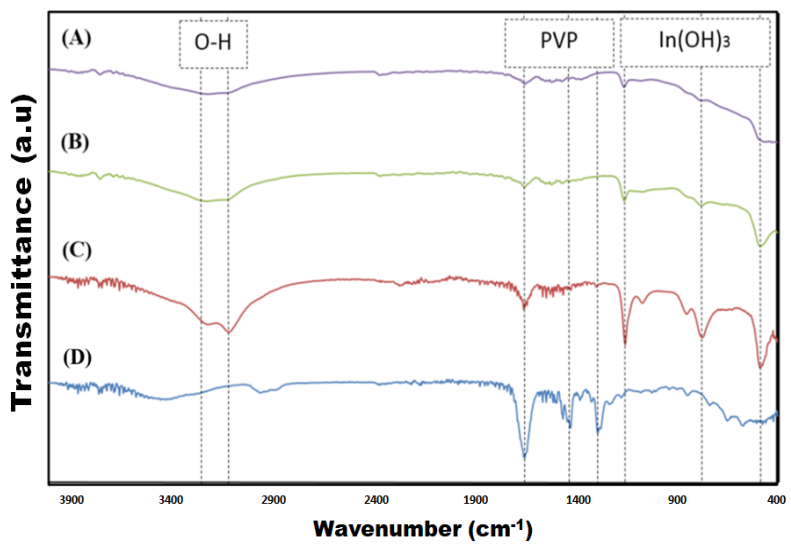

Figure 5. FTIR spectra of (A) $\mathrm{Fe}_{3} \mathrm{O}_{4} / \mathrm{In}(\mathrm{OH})_{3}$; (B) $\mathrm{Fe}(\mathrm{OH})_{3} / \mathrm{In}(\mathrm{OH})_{3} ;(\mathrm{C}) \operatorname{In}(\mathrm{OH})_{3}$ and (D) PVP. PVP was present in samples (A-C), imparting colloidal stability and water dispersibility. Without PVP, products settled as bulk materials (see Supporting Information Figure S6). comes paramagnetic or superparamagnetic when its dimension is reduced to nanoscale. This shift from a permanent and strong ferromagnetism to superparamagnetism plays an important role in catalysis as it allows the catalyst to be reused or recycled by applying an external magnet field at choice [21,22]. $\mathrm{Fe}_{3} \mathrm{O}_{4} / \mathrm{In}(\mathrm{OH})_{3}$ nanocomposite produced in this work is considered superparamagnetic as it could be readily dispersed in water and captured/recovered by a permanent magnet as present in the inset of Figure 3(A).

\subsection{Fourier-Transform Infrared (FT-IR) Analy-} sis

The presence of PVP as stabilizing agent in $\mathrm{In}(\mathrm{OH})_{3}, \mathrm{Fe}(\mathrm{OH})_{3} / \mathrm{In}(\mathrm{OH})_{3}$ and $\mathrm{Fe}_{3} \mathrm{O}_{4} / \mathrm{In}(\mathrm{OH})_{3}$ was confirmed by FT-IR analysis. The strong carbonyl stretching signal from PVP at 1652 $\mathrm{cm}^{-1}$ together with the $\mathrm{C}-\mathrm{H}$ and $\mathrm{C}-\mathrm{N}$ stretching at $1419 \mathrm{~cm}^{-1}$ and $1282 \mathrm{~cm}^{-1}$ were observed in all samples in Figure $5[23,24]$. The $\mathrm{O}-\mathrm{H}$ stretching originating form $\operatorname{In}(\mathrm{OH})_{3}\left(3207 \mathrm{~cm}^{-1}\right.$ and $3101 \mathrm{~cm}^{-1}$ ) were observed in all three samples synthesized (see Figure 5 A-C). The signal for $\mathrm{Fe}-\mathrm{O}$ in the fingerprinting region around $600 \mathrm{~cm}^{-1}$ was not very distinctive in the $\mathrm{Fe}_{3} \mathrm{O}_{4} / \mathrm{In}(\mathrm{OH})_{3}$ sample, likely due to the relatively small amount of $\mathrm{Fe}_{3} \mathrm{O}_{4}$ present and the overlapping of signals [22,25]. In a control experiment in which indium hydroxide was synthesized without the presence of PVP, bulk precipitate of $\operatorname{In}(\mathrm{OH})_{3}$ was obtained which was difficult to disperse (see Supporting Information Figure S6). PVP bestows excellent water dispersibility and colloidal stability and exert particle size control by preventing particle coalescence because of steric hindrance between the long polymer chains of PVP chemically bonds to the surface metal ions [26,27].

\subsection{Dynamic Light Scattering for Particle Size and Zeta Potential Measurement}

Dynamic light scattering (DLS) was employed to determine the sizes of the particles in terms of hydrodynamic diameters since the nanocomposite was to be used as photocatalyst in water and the colloidal stability must be quantified via the measurement of zetapotential. In Figure 6 A the DLS results shows that particles size was around $100 \mathrm{~nm}$, slightly bigger than the size determined by SEM and TEM. This is in congruence with the fact that the hydrodynamic diameter measurement take into account the volume of a surfactant and solvent surrounding the nanoparticles [28,29]. From Figure 6 B, PVP-stabilized $\mathrm{Fe}_{3} \mathrm{O}_{4} / \mathrm{In}(\mathrm{OH})_{3}$ 
exhibited a larger zeta potential value of +25.5 $\mathrm{mV}$ while PVP-stabilized $\operatorname{In}(\mathrm{OH})_{3}$ recorded a $+20.9 \mathrm{mV}$. Both values are closer to the upper end of the range of $-30 \mathrm{mV}$ to $+30 \mathrm{mV}$ commonly regarded as having sufficient repulsive force to afford high colloidal stability [29]. The positive zeta potential of $\operatorname{In}(\mathrm{OH})_{3}$ nanoparticles also provided tell-tale sign that the $\mathrm{Fe}_{3} \mathrm{O}_{4} / \mathrm{In}(\mathrm{OH})_{3}$ should deposit on the negatively charged cathode during the electrochemical reduction of $\mathrm{Fe}(\mathrm{OH})_{3}$ to $\mathrm{Fe}_{3} \mathrm{O}_{4}$.

\subsection{Photocatalytic Degradation of Methylene} Blue (MB) Catalysed $\mathrm{Fe}_{3} \mathrm{O}_{4} / \mathrm{In}(\mathrm{OH})_{3}$ Nanocomposite

To gain insights of the photocatalytic performance of $\mathrm{Fe}_{3} \mathrm{O}_{4} / \mathrm{In}(\mathrm{OH})_{3}$ nanocomposite, a study involving the photodegradation of MB promoted by simulated solar radiations at $25{ }^{\circ} \mathrm{C}$ and $\mathrm{pH} 7$ was conducted.
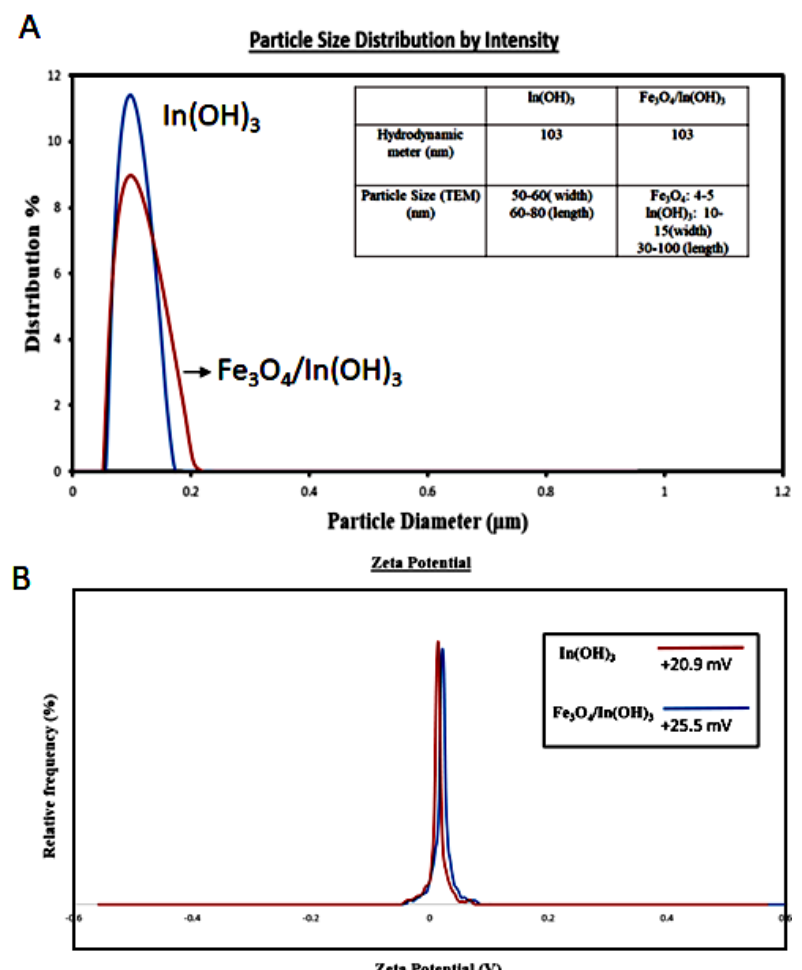

Figure 6. (A) Hydrodynamic size estimation for $\mathrm{In}(\mathrm{OH})_{3}$ and $\mathrm{Fe}_{3} \mathrm{O}_{4} / \mathrm{In}(\mathrm{OH})_{3}$. Hydrodynamic size is known to be larger than the physical size measured in a TEM or a SEM in which dried samples are required. The slightly larger size of $100 \mathrm{~nm}$ is consistent with the particles size of both $\operatorname{In}(\mathrm{OH})_{3}$ and $\mathrm{Fe}_{3} \mathrm{O}_{4} / \operatorname{In}(\mathrm{OH})_{3}$ observed; (B) The zeta potential values measured at $+25.5 \mathrm{mV}$ and $+20.9 \mathrm{mV}$ for $\mathrm{Fe}_{3} \mathrm{O}_{4} / \mathrm{In}(\mathrm{OH})_{3}$ and $\mathrm{In}(\mathrm{OH})_{3}$ respectively, indicating both should form stable colloidal solution. Both were stabilized by PVP (evidenced by the FT-IR analysis in Figure 5).
The test solutions were kept in dark with constant stirring for $1 \mathrm{~h}$ prior to studying its photocatalytic activity. The photodegradation efficiency of MB after 1 hour in the presence of $25 \mathrm{mg}$ of $\mathrm{Fe}_{3} \mathrm{O}_{4} / \mathrm{In}(\mathrm{OH})_{3}$ further stabilized on carbon on carbon was $83 \%$, while a blank control recorded insignificant changes (see Figure 7). $\operatorname{In}(\mathrm{OH})_{3}$ and $\mathrm{Fe}(\mathrm{OH})_{3} / \mathrm{In}(\mathrm{OH})_{3}$ analogues recorded circa $10 \%$ and $23 \%$ degradation after $1 \mathrm{hr}$. The significantly higher degradation efficiency observed for $\mathrm{Fe}_{3} \mathrm{O}_{4} / \mathrm{In}(\mathrm{OH})_{3}$ nanocomposite proved that it is photocatalytically active under solar radiation and should be able to perform as a good magnetically recoverable photocatalyst [30], although future optimization to achieve higher photodegradation efficiency is needed. The carbon on which $\mathrm{Fe}_{3} \mathrm{O}_{4} / \mathrm{In}(\mathrm{OH})_{3}, \quad \mathrm{Fe}(\mathrm{OH})_{3} / \mathrm{In}(\mathrm{OH})_{3}$ and $\operatorname{In}(\mathrm{OH})_{3}$ were dispersed on is not a photocatalyst but to provide better dispersibility for magnetic sample which under magnetic stirring setup for long period of time as previously reported [13].

The results demonstrated in Figure 7 clearly indicates that $\mathrm{Fe}_{3} \mathrm{O}_{4} / \mathrm{In}(\mathrm{OH})_{3}$ has a much higher photocatalytic performance amongst the three which is likely due to following: (1) More efficient solar light absorption due to the band gap of $\mathrm{Fe}_{3} \mathrm{O}_{4} / \mathrm{In}(\mathrm{OH})_{3}$ was tuned to the visible region at $2.9 \mathrm{eV}$. Band gap energy of $\mathrm{Fe}(\mathrm{OH})_{3} / \mathrm{In}(\mathrm{OH})_{3}$ and $\operatorname{In}(\mathrm{OH})_{3}(3.3 \mathrm{eV})$ are in the UVB UVC (4.6) range; (2) The close contact

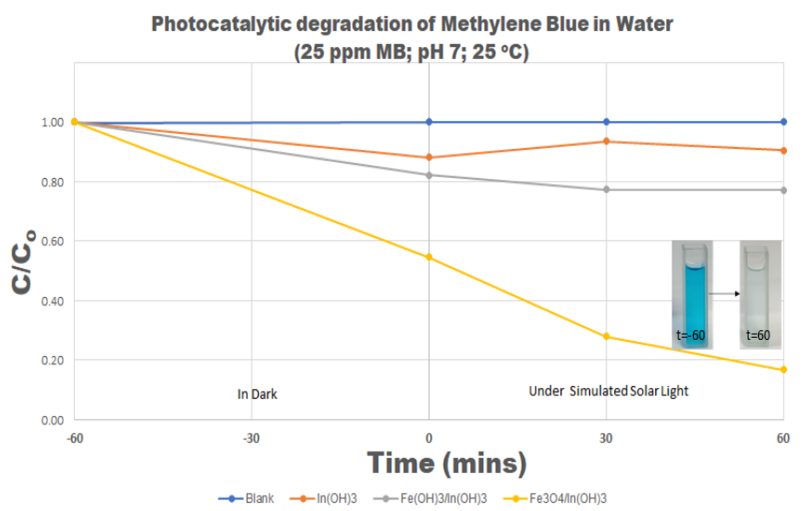

Figure 7. Photocatalytic degradation effect exerted by $\mathrm{Fe}_{3} \mathrm{O}_{4} / \mathrm{In}(\mathrm{OH})_{3}$ were compared to $\mathrm{In}(\mathrm{OH})_{3}$ and $\mathrm{Fe}(\mathrm{OH})_{3} / \operatorname{In}(\mathrm{OH})_{3}$ intermediate. Simulated solar light was then turned on and samples taken at 30 mins interval. After 1 hour, the photocatalytic degradation efficiency observed were $83 \%, 23 \%$ and $10 \%$ for $\mathrm{Fe}_{3} \mathrm{O}_{4} / \mathrm{In}(\mathrm{OH})_{3}, \quad \mathrm{Fe}(\mathrm{OH})_{3} / \mathrm{In}(\mathrm{OH})_{3}$ and $\operatorname{In}(\mathrm{OH})_{3}$ respectively. The faint blue coloured solution at the end of the study is congruent with the high degradation efficiency of $\mathrm{Fe}_{3} \mathrm{O}_{4} / \mathrm{In}(\mathrm{OH})_{3}$ after its removal via a syringe filter prior to a UV-Vis measurement. 
between $\mathrm{Fe}_{3} \mathrm{O}_{4}$ and $\mathrm{In}(\mathrm{OH})_{3}$ as a result of $\mathrm{Fe}_{3} \mathrm{O}_{4} / \mathrm{In}(\mathrm{OH})_{3}$ nanocomposite being produced from integrating hydroxide co-precipitation reaction with a cathodic reduction. The interfaces created are expected to trap electrons and holes more effectively therefore leading to the enhanced catalytic activity observed. This observation is similar to that reported for $\operatorname{In}(\mathrm{OH})_{3}$ nanorods in reports by Wan et al. and Wang et al. separately $[9,15] ;(3)$. The $\operatorname{In}(\mathrm{OH})_{3}$ moiety present in $\mathrm{Fe}_{3} \mathrm{O}_{4} / \mathrm{In}(\mathrm{OH})_{3}$ was in the form of nanorods rather than cubes and therefore were expected to exhibit higher surface area as reported recently for $\mathrm{In}(\mathrm{OH})_{3}$ and $\mathrm{CeO}$ nanorods $[15,16,18]$. This beneficial property, when combined with Point 1 and 2 led to faster adsorption and photocatalytic degradation.

Table 2 summarizes key results relevant to the characterization and photocatalytic activities reported in the previous section. $\mathrm{Fe}(\mathrm{OH})_{3} / \mathrm{In}(\mathrm{OH})_{3}$ was an intermediate with no magnetic properties nor significant effect in improving the photocatalytic activity and was not studied as detailed as the other two.

\section{Conclusion}

In summary, a new nanocomposite, denoted as $\mathrm{Fe}_{3} \mathrm{O}_{4} / \mathrm{In}(\mathrm{OH})_{3}$ was successfully synthesized using a green approach by coupling a hydroxide co-precipitation method to the electrochemical reduction of $\mathrm{Fe}(\mathrm{OH})_{3}$ to $\mathrm{Fe}_{3} \mathrm{O}_{4}$, both of which was conducted under ambient conditions. The nanocomposite comprised of unique $\operatorname{In}(\mathrm{OH})_{3}$ nanorods with an aspect ratio of 2-3 which were uniformly decorated with $\mathrm{Fe}_{3} \mathrm{O}_{4}$ nanoparticles of $4-5 \mathrm{~nm}$ in diameter. The incorporation of low bandgap $\mathrm{Fe}_{3} \mathrm{O}_{4}$ to $\mathrm{In}(\mathrm{OH})_{3}$ bestowed the $\mathrm{Fe}_{3} \mathrm{O}_{4} / \mathrm{In}(\mathrm{OH})_{3}$ its superparamagnetic property and effectively reduced the bandgap from 4.6 $\mathrm{eV}$ observed in $\mathrm{In}(\mathrm{OH})_{3}$ to $2.86 \mathrm{eV}$ which allows more efficiently absorption of solar radiation. The $\mathrm{Fe}_{3} \mathrm{O}_{4} / \mathrm{In}(\mathrm{OH})_{3}$ nanocomposite stabilized on carbon was able to remove and degrade an overall of $83 \%$ of methylene blue within $1 \mathrm{hr}$ at room temperature under the illumination of so- lar radiation, which shows that it is photocatalytically active. Future work include optimization of the photodegradation conditions to achieve higher degradation efficiency under solar radiation.

\section{Acknowledgement}

The authors thank the Ministry of Higher Education Malaysia for providing a FRGS grant under the Fundamental Research Grant $\mathrm{S}$ c h e m e ( G r a n t $\quad \mathrm{Num} \mathrm{ber:}$ FRGS/1/2020/STG05/TARUC/02/1).

\section{References}

[1] Liu, J., Zhang, J. (2020). Nanointerface Chemistry: Lattice-Mismatch-Directed Synthesis and Application of Hybrid Nanocrystals. Chemical Reviews, 120(4), 2123-2170. DOI: 10.1021/acs.chemrev.9b00443

[2] Li, X., Yu, J., Jaroniec, M., Chen, X. (2019). Cocatalysts for Selective Photoreduction of $\mathrm{CO}_{2}$ into Solar Fuels. Chemical Reviews, 119 ( 6 ), $\quad 3962-4179$. D O I : 10.1021/acs.chemrev.8b00400

[3] Astuti, Y., Andianingrum, R., Haris, A., Darmawan, A. (2020). The Role of $\mathrm{H}_{2} \mathrm{C}_{2} \mathrm{O}_{4}$ and $\mathrm{Na}_{2} \mathrm{CO}_{3}$ as Precipitating Agents on The Physichochemical Properties and Photocatalytic Activity of Bismuth Oxide. Open Chemistry, 18(1), 129-137. DOI: 10.1515/chem2020-0013

[4] Nasralla, N., Yeganeh, M., Astuti, Y., Piticharoenphun, S., Šiller, L. (2018). Systematic study of electronic properties of $\mathrm{Fe}$-doped $\mathrm{TiO}_{2}$ nanoparticles by X-ray photoemission spectroscopy. Journal of Materials Science: Materials In Electronics, 29(20), 17956-17966. DOI: $10.1007 / \mathrm{s} 10854-018-9911-5$

[5] Nasralla, N., Yeganeh, M., Astuti, Y., Piticharoenphun, S., Shahtahmasebi, N., Kompany, A., Karimipour, M., Mendis, B.G., Poolton, N.R.J., Šiller, L. (2013). Structural and spectroscopic study of Fe-doped $\mathrm{TiO}_{2}$ nanoparticles prepared by sol-gel method. Scientia Iranica, 20(3), 1018-1022. DOI: 10.1016/j.scient.2013.05.017

Table 2. Summary of characterization and properties of $\operatorname{In}(\mathrm{OH})_{3}$ and $\mathrm{Fe}_{3} \mathrm{O}_{4} / \operatorname{In}(\mathrm{OH})_{3}$.

\begin{tabular}{|c|c|c|c|c|c|c|c|c|c|}
\hline & DLS & PDI & \multicolumn{2}{|c|}{ TEM } & EDS & $\mathrm{Z}$ & $E_{\mathrm{g}}$ & $\mathrm{PE}$ & $c_{\mathrm{m}}$ \\
\hline & $\begin{array}{l}\text { size } \\
(\mathrm{nm})\end{array}$ & $\%$ & shape & size (nm) & wt $\%$ & $\mathrm{mV}$ & $\mathrm{eV}$ & $\%$ & $\mathrm{~cm}^{3} \cdot \mathrm{g}^{-1}$ \\
\hline${ }^{a} \operatorname{In}(\mathrm{OH})_{3}$ & 103 & 8.2 & Cuboid & $50-60$ & $0: 1$ & +25.5 & 4.6 & 10 & $-2.5 \times 10^{-7}$ \\
\hline${ }^{\mathrm{b}} \mathrm{Fe}_{3} \mathrm{O}_{4} / \mathrm{In}(\mathrm{OH})_{3}$ & 103 & 17.1 & $\begin{array}{l}\text { spheroid/ } \\
\text { rods }\end{array}$ & $\begin{array}{c}4-5 / \\
33^{c} \\
70-100^{d}\end{array}$ & $1: 5$ & +20.9 & 2.9 & 83 & $1.30 \times 10^{-5}$ \\
\hline
\end{tabular}

Note: Hydrodynamic diameter by Dynamic Light Scattering (DLS); Polydisperse Index (PDI); Zeta Potential (Z); Band Gap ( $\left.E_{\mathrm{g}}\right)$; Photodegradation Efficiency (PE); Magnetic Susceptibility $\left(c_{\mathrm{m}}\right)$

a: Dzhalindite (ICDD: 98-003-5637); b: Magnetite (ICDD-98-015-9967); c: Average width of nanorods; d: Length of nanorod 
[6] Rueda-Marquez, J., Levchuk, I., Fernández Ibañez, P., Sillanpää, M. (2020). A critical review on application of photocatalysis for toxicity reduction of real wastewaters. Journal of Cleaner Production, 258, 120694. DOI: 10.1016/j.jclepro.2020.120694

[7] Al-Mamun, M., Kader, S., Islam, M., Khan, M. (2019). Photocatalytic activity improvement and application of $\mathrm{UV}-\mathrm{TiO}_{2}$ photocatalysis in textile wastewater treatment: A review. Journal of Environmental Chemical Engineering, $7(5), \quad 103248$. DOI: 10.1016/j.jece.2019.103248

[8] Gao, C., Low, J., Long, R., Kong, T., Zhu, J., Xiong, Y. (2020). Heterogeneous Single-Atom Photocatalysts: Fundamentals and Applications. Chemical Reviews, 120(21), 1217512216. DOI: 10.1021/acs.chemrev.9b00840

[9] Wan, Z., Hu, M., Hu, B., Yan, T., Wang, K., Wang, X. (2020). Vacancy induced photocatalytic activity of $\mathrm{La}$ doped $\mathrm{In}(\mathrm{OH})_{3}$ for $\mathrm{CO}_{2}$ reduction with water vapor. Catalysis Science \& Technology, 10(9), 2893-2904. DOI: 10.1039/D0CY00029A

[10] Zhang, X., Wang, J., Dong, X., Lv, Y. (2020). Functionalized metal-organic frameworks for photocatalytic degradation of organic pollutants in environment. Chemosphere, 242,

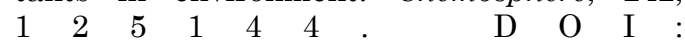
10.1016/j.chemosphere.2019.125144

[11] Hu, B., Hu, M., Guo, Q., Wang, K., Wang, X. (2019). In-vacancy engineered plate-like $\mathrm{In}(\mathrm{OH})_{3}$ for effective photocatalytic reduction of $\mathrm{CO}_{2}$ with $\mathrm{H}_{2} \mathrm{O}$ vapor. Applied Catalysis $B$ : Environmental, 253, 77-87. DOI: 10.1016/j.apcatb.2019.04.046

[12] Marin, G., Qadir, M., Fernandes, J., Castegnaro, M., Morais, J., Baptista, D., Dupont, J. (2019). Photoreforming driven by indium hydroxide/oxide nano-objects. International Journal of Hydrogen Energy, 44(47), 2569525705. DOI: 10.1016/j.ijhydene.2019.08.060

[13] Wong, P.M., Juan, J.C., Lai, J.C., Lim, T.H. (2020). Galvanic Replacement-Enabled Synthesis of $\operatorname{In}(\mathrm{OH})_{3} / \mathrm{Ag} / \mathrm{C}$ Nanocomposite as an Effective Photocatalyst for Ultraviolet C Degradation of Methylene Blue. ACS Omega, 5 (23), $\quad 13719-13728$. D O I : 10.1021/acsomega.0c00881

[14] Ashraf, M., Khan, I., Usman, M., Khan, A., Shah, S.S., Khan, A.Z., Saeed, K., Yaseen, M., Ehsan, M.F., Tahir, M.N., Ullah, N. (2019). Hematite and Magnetite Nanostructures for Green and Sustainable Energy Harnessing and Environmental Pollution Control: A Review. Chemical Research in Toxicology, 33(6), $\begin{array}{lllllllllllllll}1 & 2 & 9 & 2 & - & 1 & 3 & 1 & 1 & . & & \text { D } & \text { O } & \text { I : }\end{array}$ 10.1021/acs.chemrestox.9b00308
[15] Wang, J., Bai, S., Wang, Y., Luo, G., Wang, T. (2020). Preparation of large $\operatorname{In}(\mathrm{OH})_{3}$ and $\mathrm{In}_{2} \mathrm{O}_{3}$ particles through a seed-mediated growth method in a microreactor. Particuology, 49, 1-8. DOI: 10.1016/j.partic.2019.04.006

[16] Wang, J., Zhang, F., Wang, Y., Luo, G. (2018). Preparation of $\operatorname{In}(\mathrm{OH})_{3}$ and $\mathrm{In}_{2} \mathrm{O}_{3}$ Nanorods through a Novel Hydrothermal Method and the Effect of Sn Dopant on Crystal Structures. Industrial \& Engineering Chemistry Research, 57(8), 2882-2889. DOI: 10.1021/acs.iecr.7b05085

[17] Holzwarth, U., Gibson, N. (2011). The Scherrer equation versus the 'Debye-Scherrer equation'. Nature Nanotechnology, 6(9), 534534. DOI: 10.1038/nnano.2011.145

[18] Yan, H., Liu, Z., Yang, S., Yu, X., Liu, T., Guo, Q., Li, J., Wang, R., Peng, Q. (2020). Stable and Catalytically Active ShapeEngineered Cerium Oxide Nanorods by Controlled Doping of Aluminum Cations. ACS Applied Materials \& Interfaces, 12(33), 37774-37783. DOI: 10.1021/acsami.0c11049

[19] Feng, Q., Li, S., Ma, W., Fan, H., Wan, X., Lei, Y., Chen, Z., Yang, J., Qin, B. (2018). Synthesis and characterization of $\mathrm{Fe}_{3} \mathrm{O}_{4} / \mathrm{ZnO}$ GO nanocomposites with improved photocatalytic degradation methyl orange under visible light irradiation. Journal of Alloys and Compounds, 737, 197-206. DOI: 10.1016/j.jallcom.2017.12.070

[20] Pirhashemi, M., Elhag, S., Habibi-Yangjeh, A., Pozina, G., Willander, M., Nur, O. (2018). Polyethylene glycol-doped $\mathrm{BiZn}_{2} \mathrm{VO}_{6}$ as a high-efficiency solar-light-activated photocatalyst with substantial durability toward photodegradation of organic contaminations. RSC Advances, 8(65), 37480-37491. DOI: 10.1039/C8RA06896H

[21] Zhou, K., Zhou, X., Liu, J., Huang, Z. (2020). Application of magnetic nanoparticles in petroleum industry: A review. Journal of Petroleum Science and Engineering, 188, 106943. DOI: $10.1016 /$ j.petrol.2020.106943

[22] Singh, K., Senapati, K., Borgohain, C., Sarma, K. (2017). Newly developed $\mathrm{Fe}_{3} \mathrm{O}_{4}-\mathrm{Cr}_{2} \mathrm{O}_{3}$ magnetic nanocomposite for photocatalytic decomposition of 4-chlorophenol in water. Journal of Environmental Sciences, 52, 333340. DOI: 10.1016/j.jes.2015.01.035

[23] Barati Darband, G., Aliofkhazraei, M., Khorsand, S., Sokhanvar, S., Kaboli, A. (2020). Science and Engineering of Superhydrophobic Surfaces: Review of Corrosion Resistance, Chemical and Mechanical Stability. Arabian Journal of Chemistry, 13(1), 17631802. DOI: 10.1016/j.arabjc.2018.01.013 
[24] Rafieian, F., Mousavi, M., Dufresne, A., Yu, Q. (2020). Polyethersulfone membrane embedded with amine functionalized microcrystalline cellulose. International Journal of Biological Macromolecules, 164, 4444-4454. DOI: 10.1016/j.ijbiomac.2020.09.017

[25] An, X., Cheng, D., Dai, L., Wang, B., Ocampo, H., Nasrallah, J. (2017). Synthesis of nanofibrillated cellulose/magnetite/titanium dioxide (NFC@ $\mathrm{Fe}_{3} \mathrm{O}_{4} @ \mathrm{TNP}$ ) nanocomposites and their application in the photocatalytic hydrogen generation. Applied Catalysis B: Environmental, $206, \quad 53-64$. D O I : 10.1016/j.apcatb.2017.01.021

[26] Heuer-Jungemann, A., Feliu, N., Bakaimi, I., Hamaly, M., Alkilany, A., Chakraborty, I (2019). The Role of Ligands in the Chemical Synthesis and Applications of Inorganic Nanoparticles. Chemical Reviews, 119(8), 48194880. DOI: 10.1021/acs.chemrev.8b00733

[27] Koczkur, K., Mourdikoudis, S., Polavarapu, L., Skrabalak, S. (2015). Polyvinylpyrrolidone (PVP) in nanoparticle synthesis. Dalton Transactions, 44(41), 17883-17905. DOI: 10.1039/C5DT02964C
[28] Mallick, H., Zhang, Y., Pradhan, J., Sahoo, M., Pattanaik, A. (2021). Influence of particle size and defects on the optical, magnetic and electronic properties of $\mathrm{Al}$ doped $\mathrm{SnO}_{2}$ nanoparticles. Journal of Alloys and Compounds, $854, \quad 1566067 . \quad$ D O I : 10.1016/j.jallcom.2020.156067

[29] Bello, A., Kim, D., Kim, D., Park, H., Lee, S. (2020). Engineering and Functionalization of Gelatin Biomaterials: From Cell Culture to Medical Applications. Tissue Engineering Part B: Reviews, 26(2), 164-180. DOI: 10.1089/ten.teb.2019.0256

[30] Ghosh, M., Mondal, M., Mandal, S., Roy, A., Chakrabarty, S., Chakrabarti, G., Pradhan, S. (2020). Enhanced photocatalytic and antibacterial activities of mechanosynthesized $\mathrm{TiO}_{2}-\mathrm{Ag}$ nanocomposite in wastewater treatment. Journal of Molecular Structure, 1211, 128076. DOI: 10.1016/j.molstruc.2020.128076 


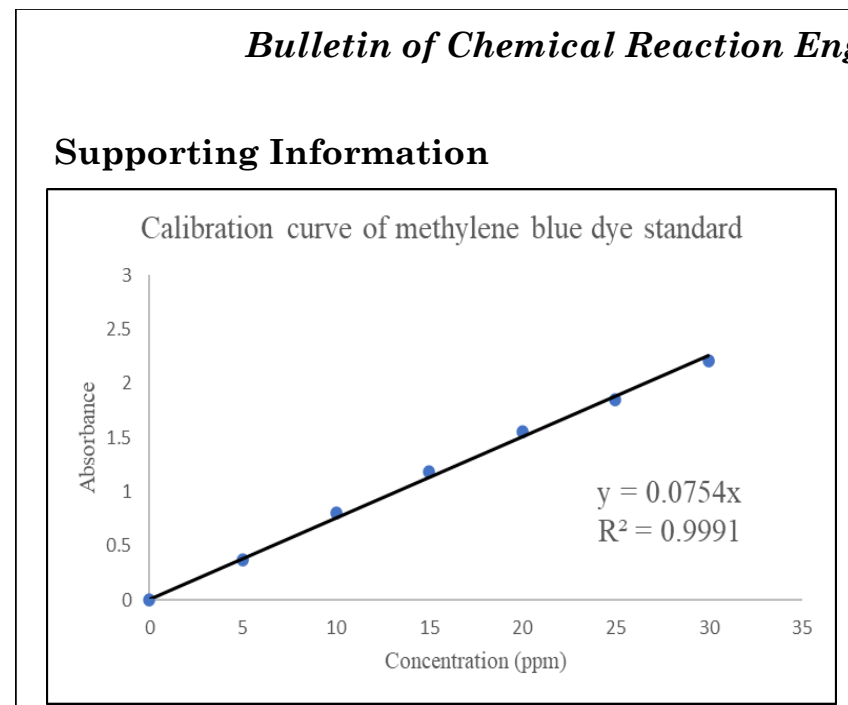

Figure S1. Calibration graph of methylene blue prior to photocatalytic degradation study

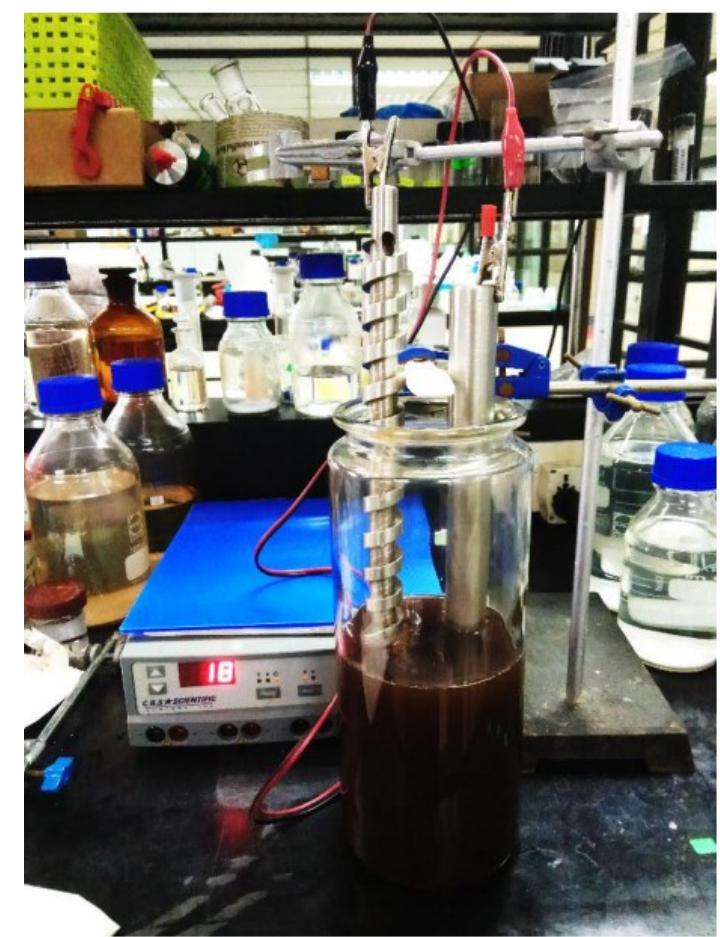

Figure S2. Cathodic reduction and electrophoretic deposition setup.

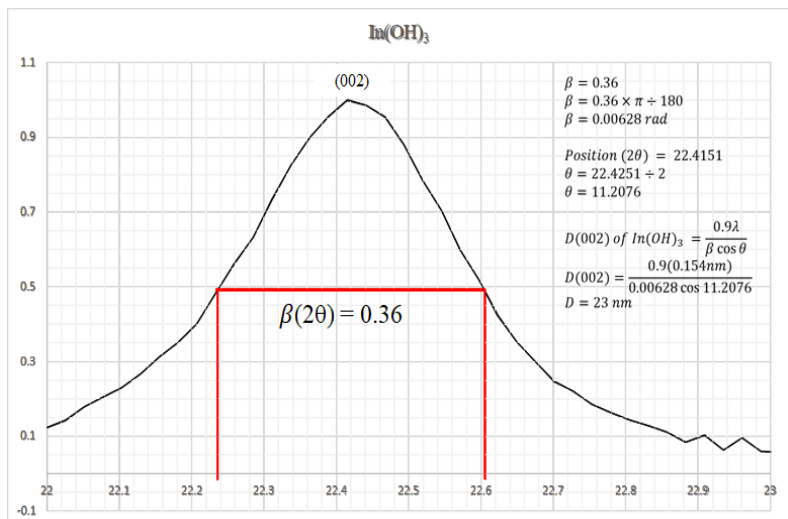

Figure S3. Average crystallite size estimated for $\mathrm{In}(\mathrm{OH})_{3}$ moiety of the $\mathrm{Fe}_{3} \mathrm{O}_{4} / \mathrm{In}(\mathrm{OH})_{3}$ nanocomposite.

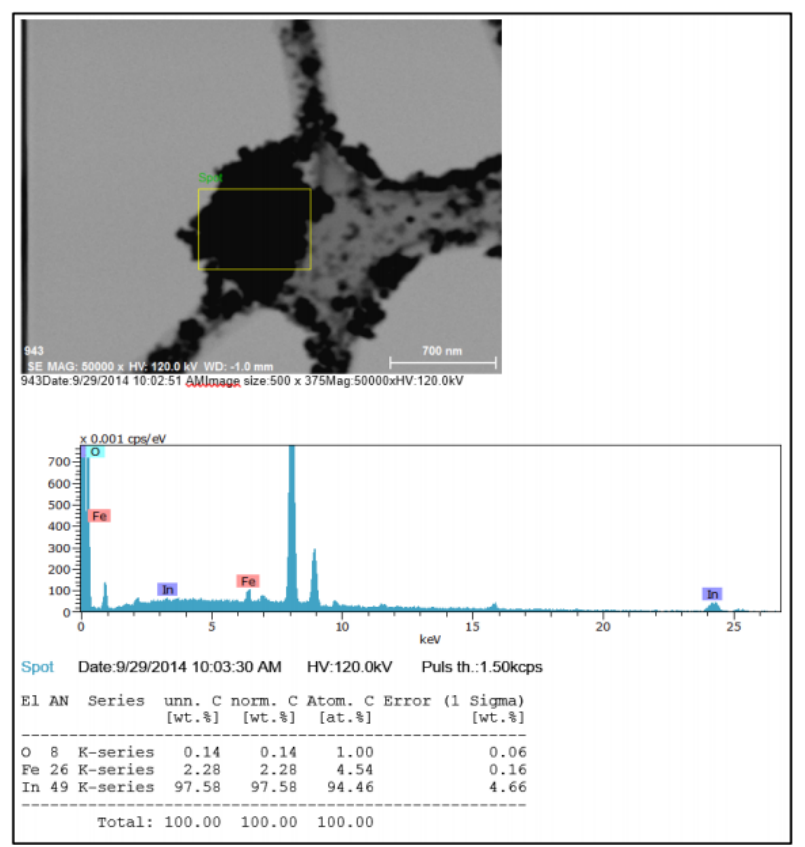

Figure S4. EDS Analysis of $\mathrm{Fe}_{3} \mathrm{O}_{4} / \mathrm{In}(\mathrm{OH})_{3}$. Fe:In ration by atom \% is $5 \%$ to 95 .

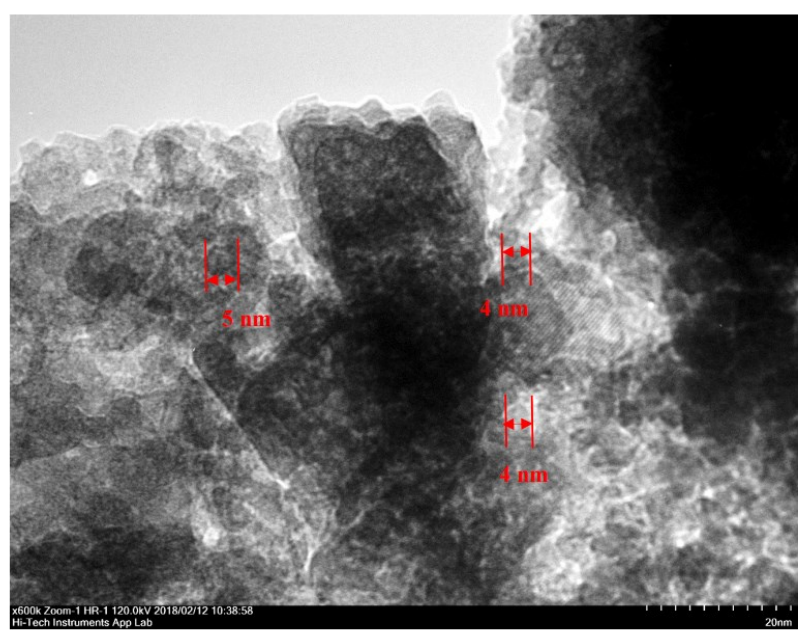

Figure S5. A bright field TEM image of $\mathrm{Fe}_{3} \mathrm{O}_{4} / \mathrm{In}(\mathrm{OH})_{3}$ shows the $\mathrm{Fe}_{3} \mathrm{O}_{4}$ surrounding $\mathrm{In}(\mathrm{OH})_{3}$ are of $4-5 \mathrm{~nm}$. 


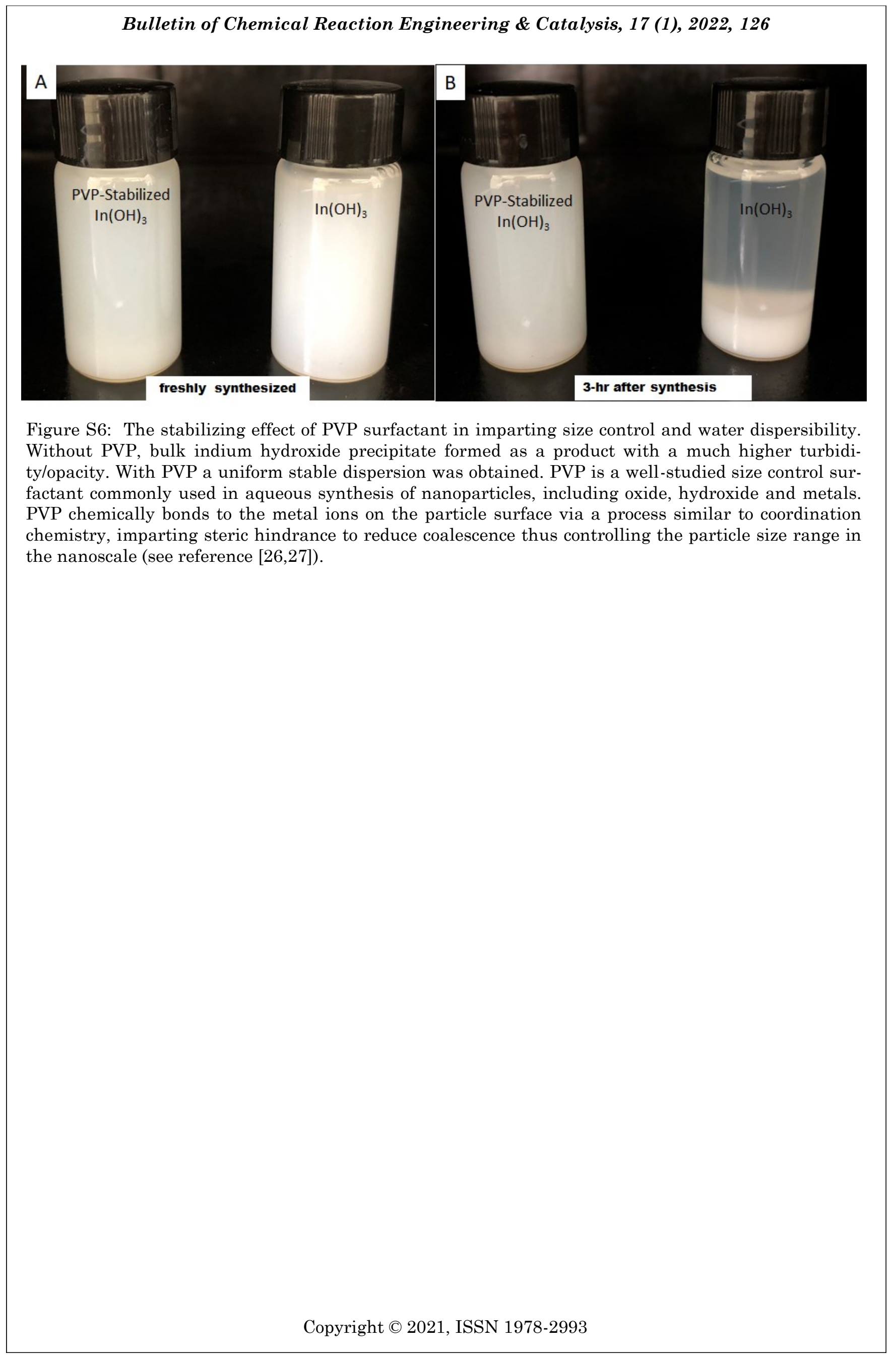

